\title{
Is there a Field of Tourism Studies?
}

\author{
Bertrand Réau ${ }^{1 *}$
}

Received: 09/12/2015 Accepted: 21/05/2016

\footnotetext{
1 Senior Lecturer, University of Paris 1 Pantheon Sorbonne-EHESS, Researcher at European Center of Sociology and Political Science (CNRS-EHESS-Paris1)-CESSP, Office $n^{\circ}$ 504, 190 avenue de France, 75013 Paris, France; email: breau@univ-paris1.fr

* Corresponding author
}

\begin{abstract}
This paper questions the status of tourism studies and invites academics to participate in an international "collective reflexivity". The author proposes conceptual and methodological tools for scientifically analysing the tourism studies area. The article articulates three dimensions of scientific activity most often treated separately: the institutional and cognitive dimensions and the analysis of audiences. The study suggests that the concept of field proposed by Bourdieu as well as the notions of "configuration" and "interdependency chains" proposed by Norbert Elias allow tourism scholars to account for these dimensions.
\end{abstract}

(C) 2016 Varna University of Management. All rights reserved

Keywords: International circulation of knowledge, sociology of science, conceptual research, methodological research, Elias, Bourdieu.

Citation: Réau, B. (2016) Is there a Field of Tourism Studies? European Journal of Tourism Research 14, pp. 5-15

"We deliberate not upon the goals themselves, but upon the means to attain them. A doctor does not ask himself if he must cure his patient, nor does an orator ask himself if he will be persuasive, nor does a politician ask himself if he will establish good laws, and in other domains one never deliberates about the goal to achieve. But once one has fixed the goal, one examines how and by what means it can be reached: and if it appears that it can be accomplished several different ways, one looks for the best and easiest way that will bring about the accomplishment."

Aristote, Ethique à Nicomaque, III,

5, 10-15 (éditions Vrin, 1990, p. 135)
"It is generally agreed that science, in its principle of finding the reason behind the phenomena, is international and even universal in its aims. But beyond this topos, the real question is that of the historically specific forms of the internationality of science." (Gingras, 2002, p. 31).

\section{Introduction}

Tourism represents a global industry, which is the subject of numerous studies. The proliferation of conferences bringing together scholars from various countries leads one to think that this subject of research constitutes a particularly "international" field of study. However, if one takes a closer look at this 
"internationalisation" one sees that it is multifaceted. Indeed, the degree of "internationalisation" of the principal journals in tourism studies, such as Annals of Tourism Research or Tourism Management remains very weak. The vast majority of the authors come from the United States, Australia, New Zealand, Scotland, Canada and Great Britain (about $77 \%$ of the authors of ATR and $65 \%$ of the authors of Tourism Management come from these countries; research done in June 15 using Web of Sciences), although there is a growing readership in China (Tribe, Xiao \& Chambers, 2012). Logically, the Englishspeaking area dominates research in terms of distribution and visibility. Yet, for a large part of non-Anglophone countries, the institutional concerns and issues surrounding publication are potentially national and/or disciplinary. And, de facto, the publications in other languages circulate little in the Anglophone universe. This weak internationalization in regards to authors in English-language journals does not, however, prevent the circulation of scholars, nor does it stop the spread of concepts, methods, and theories between North America, Great Britain, other European countries, Australia and Asia. How does this circulation of ideas and people function? Does a "field" (as defined by Bourdieu (see for instance, 1997)) of tourism studies exist? And if so, does it exist at an international level or only in national spaces?

In order to answer these questions, a theoretical and methodological framework that allows one to grasp the emergence, development and the structuring of tourism studies must be defined. Tribe (1997) shows that approximately two large branches of study on tourism exist (one being commercial and the other in social sciences), but what ties do they maintain with each other (Xiao \& Smith, 2006)? How should we judge the academic work that deals with tourism as a peripheral element of research? There were very few researchers who first started working on tourism in the Anglophone world and they were relatively isolated (Nash, 2007). According to Dean MacCannell, the majority of these scholars did not set out to make 'tourism' a permanent research subject. Tourism was considered a phenomenon permitting the study of social, historical and psychological transformations (interview with Dean MacCannell, Paris, May $20^{\text {th }}$ 2014). How should we explain the development of this field of study? Starting in the 1990s, the epistemology of research on tourism gave rise to numerous debates. Xiao \& Smith (2007) and Beckendorff \& Zehrer (2013) mentioned different publications, which produced such debates. Among the many inquiries taken up during these debates, two crossdisciplinary questions can be distinguished: Can tourism be considered as a science in its own right that takes on different names (tourismology, tourology, etc.)? Or conversely, is tourism indebted to a multi-disciplinary approach and does it therefore represent a sub-space in the various disciplinary spaces that are concerned? Darbellay \& Stock (2012a) show that a science of tourism is not on the agenda. The epistemological question about the status and the integration of knowledge invites us to lead a "collective reflexivity" concerning tourism studies. This "reformist reflexivity", according to Pierre Bourdieu, "is not something done by one person alone (...) it can exert its full effect only if it is incumbent upon all of the agents engaged in the field. The epistemological vigilance (...) that each researcher can apply on his/her own behalf can only be strengthened by the generalizing of the imperative of reflexivity" (Bourdieu, 2004, p. 91). In order to fuel the discussion about what this collective work of reflexivity could be, this article proposes leads for analysing Tourism Studies. Three conceptual and methodological approaches will be presented and discussed: networks analysis, the concept of figuration by Norbert Elias and the concept of field by Pierre Bourdieu.

\section{For a Scientific Approach of Tourism Studies}

Because it is made up of institutions (departments, universities, academic journals, professional associations, conventions, etc.) but also practices (research operations, forms of engagement) and of knowledge that addresses itself to different readerships and that circulates, an analysis of science must articulate the different dimensions (institutions, practices, contents, publics). These dimensions are intimately linked. What is important is knowing how to understand their articulation. 


\section{Paradigm and disciplines}

The sociology of science proposed by Merton (1973) focuses on the social functions of science through the study of the role of research. Consequently, it ignores the content of scientific production, which is an epistemological question. However this does not mean that we must solely concentrate on the cognitive dimension of science and abandon the analysis of scientific institutions. These two dimensions, institutional and cognitive, are important. In fact, a lot of researchers have underlined the heterogeneity of knowledge about tourism therefore rendering the emergence of a common paradigm impossible (Darbellay \& Stock, 2012b, Tribe, Xiao \& Chambers, 2012; Tribe, 1997; Benckendorff \& Zehrer, 2013). However, the concept of Kuhn's paradigm (1962) relies on the assumption of a homogeneity of disciplines that does correspond to the historical reality. Everything happens as if a scientific revolution in a discipline changes the whole discipline dramatically. Kuhn "never shows how all these components (theory, methodology, instruments) hold together if it is not by suggesting that it is the theory that constitutes the foundation of the paradigm" (Ragouet \& Shinn 2005, p.62). Yet, if the Tourism Studies are heterogeneous in their scientific production, they are also heterogeneous in their institutional networking. If one agrees to consider that studies on tourism do not constitute a paradigm, one must also take into account the fact that the disciplines are not unified. It is, on the contrary, on account of this "indiscipline" (Tribe, 1997) that the studies of tourism can hope to produce a more integrated knowledge (inter-, even, transdisciplinary), and not a simple juxtaposition of disciplinary expertise. The scientific disciplines have seen a strong internal differentiation: the disciplines are heterogeneous and autonomous (Galison, 1997). Next to the differentiated scientific fields, stable and durable, there are transversal mechanisms of communication. Zones of exchange from a mumbo jumbo shared by the different disciplines allow for the convergence (Ragouet \& Shinn, 2005, p.64). But for that, one must previously identify the meeting points, the circulation of concepts, theories and methods between disciplines, but also (and most importantly) between the specific fractions of each discipline. Fractions that vary according to national disciplinary divisions, the interests of researchers, linguistic, material and intellectual possibilities of the circulations of concepts, theories, and methods. In this sense, it is a question of conducting an analysis of Tourism Studies that relies on three observations: "The relative autonomy of the scientific field, which means that it is at once endowed with mechanisms of regulations that are specific to this particular field and that it links with the other social microcosms, economic and political fields, etc., relationships of interdependency; the existence of transversal migratory flows to disciplinary spaces concerning the practitioners as much as the concepts or the tools, which the "antidifferentiationists" (for example, the disciples of the "Strong Program" in the science of science) have studied but who only see a confirmation of the disappearance of borders, notably disciplinary ones; the persistence of the movement of intellectual convergence and of cognitive capitalization transcending the disciplinary demarcations as well as the stabilization of the sub fields of research" Ragouet \& Shinn, 2005, p. 145).

In order to conduct this analysis in a relational, dynamic and multidimensional way, three conceptual options are discussed: network, figuration and field.

\section{Network analysis}

The heterogeneity of Tourism Studies theoretically lends itself well to an analysis in terms of networks (Scott, 2000; Kolaczyk, 2009; Gingras, 2013), that they be interindividual (Tribe, 2010), institutional or bibliometric (Benckendorff \& Zehrer, 2013).

\section{Social Networks}

A social network can be defined as a set of relations between social units (Mercklé, 2011, p. 3-4). It is thus a question of "taking for objects of study not the attributes of individuals (their age, profession, etc.), but the relationships between the individuals, whether they take place face to face or at a distance thanks to different ways of communication, and the regularities that they present, to describe them, show their formation and their transformations, analyse their effects on the behaviour of individuals" (Mercklé, 2011, p. 4). 
Consequently, these methods allow for the understanding of the heterogeneity of institutional and/or interindividual relations. For example, Tribe (2010) uses this concept of "networks" in a qualitative way. Using in-depth interviews, he analyses questions asked via email and documents on the 67 subjects of the creation of "territories" and "tribes". He shows, in particular, the importance of universities and of "clans" in the productions by academic networks. In this way, a systematic statistical approach would allow for a more in-depth study of these first analyses.

Such an in-depth study must keep in mind that the networks are social and historical productions (Boltanski \& Chiapello, 1999, p. 228-229). They are produced by individuals who are not uniquely endowed with relational attributes, but also social ones (age, sex, profession, income) (Denord, 2005). The networks depend on material, symbolic and/or institutional resources that allow them to develop a structure (Tribe, 2010). The unequal endowments of resources (material, in terms of prestige, status, etc.) of individuals and of institutions have an influence on the positions occupied in the academic network. It is not because networks of Tourism Studies are more or less institutionalized depending on the era, country, specific subjects, disciplines that the researchers do not belong to institutions and that they were not trained in specific institutions (Nash, 2007; Dann \& Parrinello, 2009, Poupeau \& Réau, 2007). The hypothesis can be made that their social and professional trajectories just as much as their current position leads them to work in a certain way. This depends particularly on the possibilities offered to them (type of department, choice of research subject, colleagues with whom they work, relationships with their administrative and university supervisors, research funding, publication area, etc.). This individual history is also a collective history of institutions fostering research on tourism. We could also hypothesize that they determine at least in part the forms of networks. The mediation, if only technical, of the placing of researchers into networks, is part of a history and rests upon the resources that must be taken into account in order to understand the scientific landscape of tourism studies.

\section{Bibliometrics}

Concerning publications, bibliometrics allows for the study of the relationships between authors, themes, subjects, and the centrality of journals in a given sector, etc. using quotations. These methods allow us to understand trends (conceptual, methodological and theoretical) and the circulation of knowledge in a defined universe. In short, these methods supply elements for an analysis of the contents of science. They were notably applied to the Annals of Tourism Research (Honggen Xiao, Stephen L.J. Smith, 2006; John Tribe, Honggen Xiao, Donna Chambers, 2012) and to a study of twelve journals in order to identify the use of statistics in tourism studies (Palmer, Sesé \& Montano, 2004). It is interesting to mobilize them for another purpose (concepts, authors, theories, qualitative methods, etc.) on a large cross-section of reviews (Cheng, Li, Petrick\& O'Leary, 2011) but bibliometrics also makes it possible to compare the co-citations of authors with conceptual references in order to understand the centrality of a theory, concept, or an author in the concerned sector (Benckendorff \& Zehrer, 2013).

Bibliometric networks are precious indicators of research production. Nevertheless, taken in isolation, this method poses several problems. First of all, the analysis of quotations and coquotations does not say anything about the meaning of the quotation: is it someone who is criticizing or agreeing wholeheartedly with the author cited? Thus, heavily cited concepts like MacCannell's "staged authenticity" could be used so often partly because of extensive diversions and interpretations (MacCannell, 2014). One might ask why certain theories circulate better than others. Therefore, "[t]he postmodern emphasis of Urry's work and its attempt to present tourism as part of a broader pattern of social and economic interactions makes it widely applicable to a range of research topics" (Benckendorff \& Zehrer, 2013, p. 139). The bibliometric network does not allow for the identification of the leaders and institutional pioneers who have, however, played an essential role in the development of journals and of interindividual networks (Benckendorff \& Zehrer, 2013, p. 143). The "international" bibliometric network is deformed given the domination of Anglo-Saxon journals 
in tourism research. There exists an effect of the literature review that automatically increases the number of articles cited and that gives therefore an obvious bonus to older articles. In a similar vein, work not translated into English and that can have an important influence in certain geographic zones of research is ignored. We must thus take into account the journals published in other languages.

Bibliometric networks are not explanatory, but remain descriptive if they are not combined with other methods. While we can define the centrality in a domain of study of theories, concepts, methods and authors, bibliometrics does not allow us to understand the conditions of the production of knowledge, nor the reasons for such a centrality. Finally, these methods do not say anything about the publics, the uses of knowledge and the reception of different theories, concepts or methods.

This is why, in order to understand the tourism studies area, we must at the same time study the institutional and cognitive conditions of the circulation of researchers (their positions) and consider how publications rely upon national disciplinary reappropriations depending on the disciplinary divisions.

\section{Elias's notion of 'Configuration'}

For Norbert Elias, the notions of 'society' and of 'individuals' do not allow us to think about social phenomena relationally. He proposes "instead of these traditional representations (...) the image of many individuals, who, by virtue of their reciprocal dependence are linked together in multiple ways, thus forming interrelated associations or configurations in which the balance of forces is more or less unstable" (Elias, (1970) 1991, p.10). It is therefore a question of starting from an image of individuals in networks, of players, by emphasizing a dimension neglected by the concept of 'network': if the players are interdependent, the network is the product of "a specific constraint that the social formations, linking men, exerts upon them" (Elias, 1970) 191, p.11); but above all, every configuration is a historical process that rests upon a crystallization of relationships of reciprocal dependence between individuals, each figuration maintaining links with other figurations. This concept has the advantage of a priori- not coming from an institutionalist point of view (of an institutional over determination) while at the same time considering that the interconnection between scholars and between institutions falls into the scope of specific histories (personal and institutional), which orientate the shapes the networks take. Nevertheless, while the concept of configuration allows for a dynamic and historicized description of networks of researchers and of institutions, it poorly accounts for the struggles and the power relations that play out in the scientific field.

\section{A Scientific sub-field?}

In order to understand the process of differentiation of autonomous social spaces, Pierre Bourdieu proposes the concept of field. Modern societies marked by a high degree of social division of labour are characterized by autonomous fields, which are relative to one another (literary fields, scientific fields, etc.). Each field possesses its own stakes and rules of the game. It is a space of conflict between agents and/or institutions. Depending on their endowments in capital, every agent looks to maximize his or her own gains. Agents struggle over the appropriation of a capital specific to each field. Thus, for the scientific field, Bourdieu defines two types of capital, a 'scientific' one that occurs with the recognition from one's peers, and another 'temporal' one, that refers to the positions of temporal power (like the president of a university, etc.) (Bourdieu, 1988). Indeed, "scientific capital is a set of properties which are the product of acts of knowledge and recognition performed by agents engaged in the scientific field and therefore endowed with the specific categories of perception that enable them to make the pertinent distinctions, in accordance with the principle of pertinence that is constitutive of the nomos of the field. This diacritical perception is only accessible to those who possess sufficient incorporated cultural capital" (Bourdieu, 2001, 2004 , p. 55). Therefore, in this scientific field, the entrance fees, so to speak, are particularly steep (doctorate, judgment by peers who are also competitors), which according to Bourdieu, renders the field autonomous (Bourdieu, 1997). 
Moreover, "scientific capital functions as a symbolic capital of recognition that is primarily, sometimes exclusively, valid within the limits of the field (although it can be converted into other kinds of capital, economic capital in particular)" (Bourdieu, 2001, 2004, p. 55). In this vein we can ask ourselves how does a symbolic capital specific to the sub-field of tourism studies develop? The cognitive and material stakes are intimately linked. Thus, the definition of the boundaries of the sub-field of tourism studies is a stake in struggles. For example, the anonymous peer reviewers of the most important/central journals control through their judgments, what is acceptable to consider as tourism and what is excluded, the methods that should be applied to the study of tourism, the legitimate theories, etc. Thus they participate in defining the limits of the imaginable in this field of study. Similarly, this makes one think of thesis committees, scientific committees for conferences and editors of multi-authored books. These spaces of scientific production participate in defining the symbolic capital specific to the sub-field of tourism studies. But this capital is not only a scientific stake in struggles, but also a material one. Indeed, "The logic of scientific struggles cannot be understood unless one takes into account the duality of the principle of domination. For example, in order to be pursued, the sciences require two types of resources, strictly scientific ones, which are for the most part incorporated, and the financial resources needed to (...) pay staff, or administrative resources, such as posts; and the competition among them, researchers must always struggle to win their specific means of production in a field where the two kinds of scientific capital are effective" (Bourdieu, 2001, 2004, p. 55).

Tourism represents an important business. In this sense, it is this subject of many professional training throughout the world. What links do researchers (who can also be teachers in these professional courses) maintain with this economic sector? (Tribe, 1997). How does scientific capital allow one to obtain financial resources that, in return, allow for the increase in scientific capital? The organization of international conferences, the large-scale circulation of publications rely upon
Subsequently, "the structure of the scientific field is defined, at every moment, by the state of the power relations between the protagonists in the struggle, in other words by the structure of the distribution of the specific capital (in its different kinds) that they have been able to accumulate in earlier struggles. On the basis of each scientist's position within it, the structure assigns to him his scientific strategies and position-takings and their objective chances of success. These position-takings are the product of the relationship between a position in the field and the dispositions (the habitus) of its occupant. Every scientific choice - the area of research, the methods used, the place of publication, (...) is also a social strategy of investment oriented towards maximization of the specific, inseparably social and scientific profit offered by the field and determined by the relationship between position and dispositions (...)" (Bourdieu, 2001, 2004, p. 59). In this sense, it could be interesting to study over time, the positions and acts of positioning by tourism scholars in different countries.

Indeed, the notion of "field" is also largely anchored in a national model of the analysis of science. Anglophone countries are not the only ones who seem to play an important role, the development and renewal of research in nonEnglish speaking countries leads us to believe that other national spaces of research exist, it therefore becomes a question of analysing the relationships between these spaces. We can therefore hypothesize that phenomena of import/export (Dezalay \& Garth, 2002) exist, (for example through the international cooptation in the scientific committees of conferences) which fit in with the national positioning strategies. If at the international level, we are faced with a network of researchers and institutions that produce particular configurations, "temporal powers tend to be more national, linked to national institutions, particularly those that govern the reproduction of the corps of scientists - such as Academies, committees, research councils, etc." (Bourdieu, 2001, 2004, p. 59). Therefore, national structuring is different and it poses differently the question of knowing the boundaries of an area of research on tourism: there are regular entries and exits, authorities of consecration seem to be most often 
disciplinary, but the disciplines do not have the same meaning in all countries, the boundaries of studies on tourism are more or less fungible with related domains like leisure activities, sports, or cultural practices. For instance, in the U.S., studies on tourism are potentially more institutionalized than in France, notably including university departments of Hospitality. Access to university positions in this domain can therefore be an issue.

Finally, one is invited to take into consideration the weight of national histories in the disciplinary and interdisciplinary divisions as well as the development of studies about tourism in order to understand the construction of national fields of tourism studies fuelled by the back and forth of processes of importexport with the other national fields.

\section{National Social Sciences Divisions}

Making the hypothesis that the Social Sciences are still to a great extent structured nationally provides the means to understand the modes of circulations, of import/export of theories, concepts, and methodologies. Theory, unlike empirical studies, "travels" better but not just any theory. The plasticity of this one, which is to say the possibility offered of diverse cognitive translations, is essential. As a case in point, we cannot understand the success of authors of French Theory (such as Foucault, Deleuze, and Derrida) in the Unites States if we do not consider the conceptual plasticity that their theories offer (Cusset, 2008). These authors fuel not only Cultural Studies (Neveu, 2008), but also considerably tourism studies (especially Foucault). For a theory to be exported, being exportable does not suffice. There also needs to be institutional conditions, reappropriations differentiated according to the disciplinary and national contexts (Cusset, 2008; Neveu, 2008). Consequently, we can ask why such or such theory or concept is imported in tourism studies, while others, just as important are neglected? Conversely, what type of knowledge about tourism circulates outside of journals on tourism (Wardle \& Buckley, 2014)? "The number of citations of tourism research in non-tourism disciplines is thus very small compared to the tens of thousands of internal citations within tourism research" (Wardle \& Buckley, 2014, p. 167).
Take for example the references to the "classic" authors of sociology in the twentieth century, which are extremely selective in Tourism Management (Research done in June 2015 using the journal's website and using the rankings of the works of the most read sociologists of the $20^{\text {th }}$ Century (ISA Books $20^{\text {th }}$ Century)). If one counts 577 appearances of the word "sociology" in the whole set of articles in this period, Norbert Elias, for example, is only cited 9 times, Max Weber only 18 times and Garfinkel, 3 times, although Foucault is the most cited (37 times). Conversely, the most cited authors are specialists of "tourism" such as John Urry (162) or Erik Cohen (358). It is not a question of saying that all the "classic" authors allow to think about the touristic phenomenon, nor is it a question of calling upon reverential quotations by the "classic" sociologists, but rather, in a collective approach, identifying the processes of circulation and of selection of patterns of thinking. From then on, talking about the configurations of tourism studies means retracing the academic and bibliometric networks by taking into account the individual and collective histories involved in a field of study. Empirically, we can lead a prosopographic study, collect biographical elements and link them to institutional histories (journals, professional associations, universities, funding for research, etc.) (Dann \& Parrinello, 2009; Nash, 2007; Tribe, 2010). We can ask a series of questions: Who are the actors in this domain of study? How were they trained? Not only in what discipline, but also in what social and cultural conditions? In which tradition of the social sciences? Which positions do they occupy and have they occupied? How does one situate these positions within the research institutions of the different countries concerned? For example, do they participate in conferences or in special issues of journals that do not deal with tourism? It is not about making a history of events, but about understanding historically the process of the creation of academics positions, current networks and relative autonomous space of science: that is to say a field.

\section{Statistical methods}

The statistical application of the concept of field works by using a Multiple Correspondence Analysis (Le Roux \& Rouanet, 2010). This 
method allows us to define a hierarchized and polarized space of positions and stances taken. In this sense, it lets us take into account the structural effects that orient the agents' stances, agents who are unequally endowed with different capital (economic, cultural and social). This method is not to be used exclusively. It is most often usefully supplemented with life trajectory interviews. But unlike first-hand accounts alone, which if they are taken as common practice, can offer a romanced and naïve vision scientific investments, MCA allows for the objectification of positions and the definition of the structure of a field. (For instance see, Bühlmann, David, Mach, 2013). In statistical terms, this method could be enhanced by network and bibliometric analyses. Multiple Correspondence Analysis, 'interindividual' networks and bibliometrics mobilize specific statistical tools that give rise to numerous debates between specialists of the social sciences and statisticians (Le Roux \& Rouanet, 2010; Gingras, 2013, Lazega, 1998, Mercklé, 2011). In order to implement the concept of "field", it is a question of mobilizing the Multiple Correspondence Analysis and the network analyses (Denord, 2005; Faust, 2005; Le Roux \& Rouanet, 2010; Kolaczyk, 2009).If the Multiple Correspondence Analysis makes it possible to polarize a space of positions using social properties, the network analysis shows the links between individuals and/or between institutions. Associating the two lets us grasp the historical (Lemercier \& Zalc, 2008) and institutional dimensions of networks in order to draw the academic field in different periods. One can, for example, study dissertation committees, the advisory committees of conferences, editorial committees or Academies, the networks, university departments, professional associations, etc. But these statistical analyses do not say anything about the contents of science. They must therefore be completed by bibliometric analyses to identify the circulation of ideas. Nevertheless, we cannot totally understand scientific production without considering to whom it is addressed. These methods do not permit to grasp either the audience, or the use of this knowledge. A final level of analysis remains essential: the study of audiences.

\section{Studying readers of tourism studies}

A contemporary of Merton, Charles Wright Mills, in his thesis Sociology and Pragmatism (1964) proposes an original system that studies audience. By associating epistemology and methodology following Dewey, he gives himself as object of study the motives of the actions of pragmatic philosophers and notably their relationship with the audience. The development of this philosophy could only take place on because of an institutional context and a receptive public (the emerging public of students in/of higher education who constitute the rising middle classes, coming from the countryside to the city and "professionalizing" themselves) (Denord \& Réau, 2014).

\section{Who read tourism studies journals?}

If we rely on this model, one must ask who is the public of tourism studies? The articles focusing on the readers of journals central in the domain provide us with precious analysis (Xiao, Smith, 2007, 2008; Xiao, Jafari, Cloke, Tribe, 2013) that could be systematized through the analysis of institutional interconnection/networking of the readership. Similarly, a focus on the use of key concepts elaborated in the domain of tourism studies (Xin, Tribe \& Chambers, 2013) through a bibliometric analysis participates in identifying the social and scientific influence of this area of research. Finally, if we can think that a part of the economic and political actors of tourism take an interest directly or indirectly in publications in this sector, one can study the elements that are mobilized by these actors, their ways of reappropriating or ignoring them (and on the contrary, how researchers do or do not use the knowledge produced by the economic and political actors of tourism). The disciples of the Actor-Network-Theory propose in this regard to go beyond the division between scholar, the subject, and the audience (Latour, 1999).

\section{Elias Historical Point of View}

According to Latour (1999), science means above all putting empirical elements taken out of context into writing: scientific knowledge is just one type of play on writing. The tourist, the travel agent, the guide, etc. also produce knowledge. In the end, the boundaries between science and the social world disappear: 
science does not have a specific status anymore. Nevertheless, all knowledge is not scientific: this is the point of producing a scientific analysis of tourism studies. We can ask ourselves what are the institutional and cognitive conditions that allow certain types of writing to nourish the touristic activity when others remain totally unknown or unused. The concept of 'functional interdependency' and the notion of 'chains of interdependency' offer the advantage of recording the individual and collective history of the circulation of knowledge, which without this historical inscription, "floats in the air" faced with the champions of the ANTs' refusal to explain and their will to only describe. Technological advances and the internationalization of exchanges considerably lengthened the "chains of interdependency" (Elias, (1970) 1991). A study of the audiences must thus accompany precise monographs that understand the configurations between producers of scientific knowledge, indigenous knowledge, tourists and touristic institutions. This approach does not find its whole meaning in completing the statistical analysis that put into context the monographs produced. We can therefore define the specific configurations of links of interdependence (Elias, 1970) 1991) between researchers, institutions, tourism's actors at different levels (which unlike a notion like that of "scientific community" avoids isolating science, in a configuration where it is potentially very open to exterior social microcosms).

\section{Conclusion}

The statistical analysis of institutional, interindividual, and bibliometric networks, and of the audiences supplies an essential framework for anchoring ethnographic studies (situated) in the chain of interdependency that characterizes the production of scientific knowledge about tourism. Familiarity with this historical and institutional context allows thus to study specific positions both past and present by retracing the "links of interdependency" between the different actors (local informers and residents, local actors in tourism, researchers, national or international actors, tourists, etc.) Using both the concept of "interdependency chains" to study the audience, and the concept of field to analyse the structure of the tourism studies area, allow scholars to avoid two pitfalls: 1. the under determination of actions theoretically in the Actor Network Theory for whom, everything happens as if the networks "floated" without any social and historical anchoring. 2."If one speaks, as Latour (1987) does, of 'nondifferentiation between the political level and the scientific level' then one may feel entitled to place scientific strategies on the same level as intrigues to win funding or scientific prizes, and to describe the scientific world as a universe in which results are won by the power of rhetoric and professional influence-as if the principle of actions were ambition backed up with strategic and warlike rhetoric and as if scientists turned their attention to this or that theme of research solely in order to climb the professional ladder, as others man oeuvre to win the Nobel Prize by surrounding themselves with a wide and dense network" (Bourdieu, 2001, 2004, p. 54). On the contrary, the concept of field permits the understanding of the specificities of the structure of the academic struggles, networks of individuals, and institutions. Indeed, "the relationship between the space of positions and the space of position-takings is not one of mechanical reflection: the space of positions exerts an effect on position-takings only through the habitus of the agents who apprehend that space, their position within it and the perception that the other agents involved in that space have of all or part of the space. The space of positions, when perceived by a habitus adapted to it (competent, endowed with a sense of the game), functions as space of possible, the range of possible ways of doing science, among which one has to choose; each of the agents engaged in the field has a practical perception of the various realizations of science, which functions as problematic. This perception, this vision, varies according to the agents' dispositions, and is more or less complete, more or less extensive; it may rule out some sectors, disdaining them as uninteresting or unimportant (scientific revolutions often have the effect of transforming the hierarchy of importance)" (Bourdieu, 2001, 2004, p. 59-60). In another hand, retracing the "chains of interdependency" between the different kinds of actors involved in tourism is considering that the academic writings depend also on the audiences in the 
production of knowledge. These links, while leaving the individual with room for freedom force the actors to act depending on games and the histories in which they are involved. That is how individual reflexivity proposed by $E$. Bruner (Bruner, 1995), which each research carries out for his/her work, deserves to be inscribed in a collective reflexivity that relies on the analysis of a field of studies and the circulation of knowledge that are produced there. The scale of such data collection and its treatment calls for the establishment of an international team of researchers.

\section{References}

Bourdieu, P. (1988). Homoacademicus. Palo Alto: Stanford University Press.

Bourdieu, P. (1997), Les usages sociaux de la science. Pour une sociologie clinique du champ scientifique, Paris : INRA editions.

Bourdieu, P. (2001, 2004) Science of science and Reflexivity. Polity Press and the University of Chicago.

Bruner, E.M. (2005). The Ethnographer/ Tourist in Indonesia. In Lanfant, M.F., Allcock, J.B. \& Bruner, E.M. International Tourism. Indentity and Change (pp. 224242). London: Sage.

Bühlmann F., David T., Mach A. (2013).Cosmopolitan Capital and the Internationalization of the Field of Business Elites: Evidence from the Swiss Case. Cultural Sociology 7(2), 211-229.

Cheng, C-K., Li, X., Petrick, J.F \& O'Leary, J.T (2011). An examination of tourism journal development. Tourism Management. 32, 53-61.

Cousin, S. \& Réau, B. (2009), Sociologie du tourisme. Paris: La Découverte.

Cousin, S. (2011). Les miroirs du tourisme. Ethnographie de la Touraine du Sud. Paris: Descartes \& Cie.

Dann, G.M.S. \& Parrinello, G.L. (2009). The Sociology of Tourism, European Origins and Developments. Tourism Social Sciences Series, vol. 12, Emerald.

Darbellay, F., \& Stock, M. (2012a). Tourism as complex interdisciplinary research object. Annals of Tourism Research. 39(1), 441458.

Darbellay, F., \& Stock, M. (2012b). Penser le touristique: nouveau paradigm ou inter disciplinarité. Retrieved May $11^{\text {th }}$ from espacestemps.net.

Denord, F. (2005).Réseaux sociaux. (Théorie des) Notionnaire de sciences sociales. Dictionnaire des idées. Paris: Encyclopedia Universalis. 697-699.

Denord, F.\& Réau, B. (2014). La sociologie de Charles Wright Mills. Paris: La découverte.

Dezalay, Y. \& Garth, B. (2002). The Internationalization of Palace Wars: Lawyers, Economists and the Contest to Transform Latin American States. Chicago: University of Chicago Press

Dunning, E. \& Elias, N. (1986). Quest for Excitement. Sport and Leisure in the Civilising Process. Oxford: Basil Blackwell.

Echtner, C.M., Jamal, T.B. (1997). The disciplinary dilemma of tourism studies. Annals of Tourism Research, 24(4), 868883.

Elias, N. (1970, 1991). Qu'est-ce que la sociologie? Paris: Agora.

EquipeMIT (2002). Tourisme 1. Lieux communs. Paris: Belin.

Faust, K. (2005). Using Correspondence Analysis for Joint Displays of Affiliation Networks. In Carrington, P. J., Scott J., and Wasserman, S., (Eds.) Models and Methods in Social Network Analysis. (pp. 117-147). New York: Cambridge University Press.

Galison, P. (1997). Image and Logic: Material Culture of Microphysics. Chicago: University of Chicago Press.

Gingras, Y. (2002). Les forms spécifiques de l'internationalité du champ scientifique. Actes de la recherché en sciences sociales, 141-142, 31-45.

Gingras, Y. (2013). Sociologie des sciences, Paris: PUF.

Gingras, Y. (2014). Les dérives de l'évaluation de la recherche. Du bon usage de la bibliométrie, Paris: Raisons d'agir

Kolaczyk, E. D. (2009). Statistical Analysis of Network Data: Methods and Models. Berlin: Springer.

Kosti, F. (2007). Les souvenirs religieux du mont Athos. Sur les frontières entre symbols sacrés et objets économiques / The religious souvenirs of Mont Athos. Actes de la recherché en sciences sociales, $170,48-58$. 
Kuhn, T. (1962). The structure of scientific revolutions. Chicago: University of Chicago Press.

L'Estoile, Benoît de. (2007). Le goût des Autres. De l'exposition coloniale aux Arts premiers. Paris: Flammarion.

Latour, B. (1987). Science in Action: How to Follow Scientists and Engineers through Society. Milton Keynes: Open University Press.

Latour, B. (1999). Pandora's Hope. Essays on the Reality of Science Studies. Cambridge, Mass: Harvard University Press.

Lazega, E. (1998). Réseaux sociaux et structures relationnelles. Paris: PUF.

Le Roux, B., Rouanet, H. (2010). Multiple Correspondence Analysis. Thousand Oaks: Sage publications.

Lemercier, C. \& Zalc, C. (2008). Méthodes quantitatives pour l'historien. Paris: La Découverte.

MacCannell, D. (2014). Comment on Lau and Knudsen/Rickly-Boyd. Annals of Tourism Research, 44, 285-287.

Mercklé, P. (2011). Sociologie des réseaux sociaux. Paris: la Découverte.

Merton, R. K. (1973). The Sociology of Sciences. Theoretical and Empirical Investigations. Chicago: University of Chicago Press.

Mills, C. W. (1964). Sociology and pragmatism: The higher learning in America. Oxford University Press.

Nash, D. (2007). The Study of Tourism, Anthropological and Sociological Beginnings. Amsterdam: Elsevier.

Neveu, E. (2008). Les voyages des cultural studies. L'Homme, 187-188 (3), 315-341.

Palmer, A. L., Sesé, A. \& Montaño, J.J. (2005). Tourism and Statistics: Bibliometric Study 1998-2002. Annals of Tourism Research, 32(1), 167-178.

Poupeau, F. \& Réau, B. (2007). L'enchante ment du monde touristique. Actes de la recherché en sciences sociales, 170, 413.

Réau, B. (2011). Les Français et les vacances. Sociologie des pratiques et offres de loisirs. Paris: editions CNRS.

Riley, R.W., \& Love, L.L. (2000). The State of Qualitative Tourism Research. Annals of Tourism Research, 27(1), 164-187.
Scott, J. (2000). Social Network Analysis. A Handbook. London: Sage.

Shinn, T. \& Ragouet, P. (2005). Controverses sur la science. Pour une sociologie transversaliste de l'activité scientifique. Paris: Raisons d'agir editions.

Stone, P., Sharpley, R. (2008). Consuming Dark Tourism: A Thanatological Perspective. Annals of Tourism Research, 35(2), 574-595.

Tribe, J. (1997). The Indiscipline of Tourism. Annals of Tourism Research, 24(3), 638657.

Tribe, J. (2010). Territories and Networks in the Tourism Academy. Annals of Tourism Research, 37(1), 7-33.

Tribe, J., Xiao, H., \& Chambers, D. (2012).The reflexive journal: inside the black box. Annals of Tourism Research, 39(1), 7-35.

Urry, J. (2002). The Tourist gaze. Sage publications.

Wardle, C. \& Buckley, R. (2014). Tourism citations in other disciplines. Annals of Tourism Research, 46, 166-168.

Wasserman, S., \& Faust, K. (1994). Social network analysis. Methods and applications. Cambridge: Cambridge University Press.

Weiler, B., Moyle, B., \& McLennan, C. (2012) Disciplines that influence tourism doctoral research: The United States, Canada, Australia and New Zealand. Annals of Tourism Research, 39(3), 1425-1445.

Xiao, H., \& Smith, S.L.J. (2006). The making of tourism research: Insights from a Social Sciences Journal. Annals of Tourism Research, 33(2), 490-507.

Xiao, H., \& Smith, S.L.J. (2007). The use of Tourism knowledge: Research Propositions. Annals of Tourism Research, 34(2), 310-331.

Xiao, H., \& Smith, S.L.J. (2008). Knowledge Impact: An Appraisal of Tourism Scholarship. Annals of Tourism Research, 35(1), 62-83.

Xiao, H., Jafari, J., Cloke, P. \& Tribe, J. (2013). Annals: $40-40$ vision. Annals of Tourism Research, 40, 352-385.

Xin, S., Tribe, J., Chambers, D. (2013). Conceptual research in tourism. Annals of Tourism Research, 41, 66-88. 